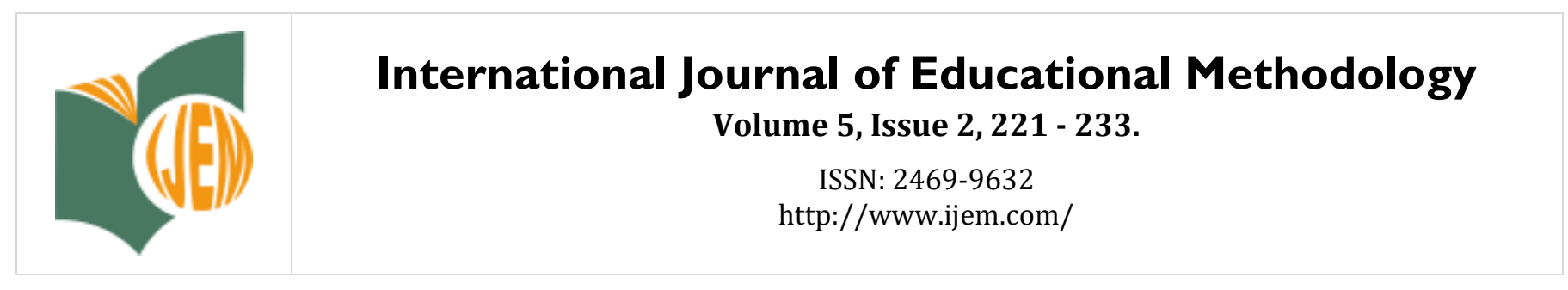

\title{
“Science Teaching and Science Teachers” from Students' Point of View
}

\author{
Esra Ucak * \\ Pamukkale University, TURKEY
}

Received: February 24, $2018 \cdot$ Revised: April 16, $2019 \cdot$ Accepted: April 23, 2019

\begin{abstract}
The current study investigated the opinions of secondary school students taking the science course from different science teachers about the science course and science teachers. The current study was conducted with the participation of 32 students instructed by different science teachers and attending different secondary schools in the fall term of 2018-2019 academic year. The data of the current study were collected by means of semi-structured interviews. In the analysis of the data, the descriptive analysis technique was used. The findings of the current study have revealed that high majority of the students love their science classes and science teachers, that in science classes, lecturing, question-answer and note-taking are methods widely employed, that if there is a smart board in the class, then Okulistik or EBA computer program is on, that the assignments given are from the textbook, that the most frequently adopted behavior by the teachers in the face of any discipline problem is warning and that informal learning environments are not used much. Moreover, it was found that projects are rarely assigned to students and the projects assigned are given as homework. A great majority of the students expect their teachers to be entertaining, they want their lessons to be instructed through games and experiments, and they do not want to write a lot in their classes.
\end{abstract}

Keywords: Science course, students' opinions, secondary school students.

To cite this article: Ucak, E. (2019). "Science teaching and science teachers" from students' point of view. International Journal of Educational Methodology, 5(2), 221-233. https://doi.org/10.12973/ijem.5.2.221

\section{Introduction}

As time goes on, societies are developing, and as societies develop, new needs emerge. Accordingly, educational services are developing and evolving to meet these needs (Gunes \& Karasah, 2016). In today's science and technology age, new information is produced and technological innovations are made. For societies to develop, they have to keep up with the changing and developing world of science and technology. In this regard, training of science literate individuals is of great importance for the future of societies (Senler, 2017). The science literacy, which is considered to be an important part of science education in many countries, is defined as "the unity of science-related skills, attitudes, values, conceptions and knowledge necessary for individuals to develop their critical thinking, problem solving and decision-making skills and to be life-long learners and to maintain their sense of curiosity about their environment and world" (MoE - [Ministry of Education], 2005, p.5). Science literate individuals can question, research, find answers to questions, define what they see in nature, make explanations and predictions about what they see and discuss the results. According to science educators, the nature of science and scientific inquiry are the main components of science literacy (Lederman, Lederman \& Antink, 2013; Roberts, 2007).

In this regard, the traditional model built on the direct transmission of the knowledge was abolished in our country, and it has been replaced with a science curriculum requiring the establishment of student-centered classroom settings where problem-based, project-based, argumentation-based, cooperation-based activities should be introduced to students. In order for students to learn information meaningfully and permanently, classroom / in-school and out-ofschool learning environments are designed according to the research-inquiry-based learning strategy. In this context, informal learning environments (school garden, science centers, museums, planetariums, zoos, botanical gardens, natural environments, etc.) are capitalized on. Performances expected from students such as the project design, model and product creation, product introduction and so on are suggested to be carried out within the classroom and under the guidance of a teacher (MoE, 2018). Therefore, in science curriculums, it is expected that teachers will prepare and implement the activities they will do or will have their students do in school according to the "research-inquiry-based" learning strategy.

\footnotetext{
* Correspondence:

Esra Ucak, Pamukkale University, Faculty of Education, Denizli, Turkey.

$\bowtie$ eucak@pau.edu.tr
} 
While scientists do research to understand the natural world, they use some scientific methods. The idea that students can reach some answers by using the same scientific methods in inquiry-based classes is not very unusual (DeBoer, 2006). From this point of view, educational scientists have begun to think that integrating the idea of students as scientist into teaching can be quite useful for educating science literate individuals (DeBoer, 2006; Puvirajah, 2007). This idea basically defines the classroom environment as a dynamic environment where students think like scientists, do research and share the results with their peers (Harlen, 2004; NRC, 2000). Therefore, inquiry-based teaching is a teaching strategy in which students create their own questions about a natural phenomenon, collect data, analyze and interpret these data, develop explanations about the phenomenon, evaluate explanations according to current knowledge and discuss these explanations with their peers in class (Byers \& Fitzgerald, 2002; NRC, 1996).

Along with the developing science and technology, there is an emerging need not only for individuals who learn how to learn, are aware of the metacognitive processes and think creatively but also for qualified teachers who will educate these individuals (Bardak \& Karamustafaoglu, 2016). The programs are renewed over time according to the requirements of the age, but only the changes made on paper are not sufficient for the science teachers to implement these programs. On the basis of the idea that this change and adaptation depends to a great extent on "what teachers' opinions are and what they do" (Fullan, 2007, p. 129). The roles to be assumed by teachers in this transformation are believed to be important. In their study analyzing the subjects of theses, Cakici and Ilgaz (2011) found teachers' opinions have been explored to a great extent yet students' opinions have been mostly overlooked. In this connection, the current study focused on students' opinions not teachers' opinions about science teaching delivered in classes.

The purpose of the current study is to determine the opinions of secondary 5th, 6th, 7th and 8th graders instructed by different science teachers and attending different secondary schools about science classes and science teachers. To this end, answers to the following questions were sought:

1. Do the students like their science classes and science teachers? Why?

2. How do the students define their science teachers' personality features and how do they want the personality features of their teachers to be?

3. How do the students think that their science teachers deliver their science classes and how do they want their classes to be instructed?

4. How do the students think that their science teachers check what has been learned in a class?

5. What kind of assignments do the students think they are given by their science teachers?

6. How do the students think their science teachers ensure discipline in the class?

7. Do the students think that their science teachers capitalize on informal learning environments? (How does it work if it uses informal learning environments?)

\section{Methodology}

The current study is a case study, one of the qualitative research methods. In this research model, one or more cases were investigated in depth, and they were explored through a holistic approach (Yildirim \& Simsek, 2011). Therefore, in order to analyze the development of the conceptual understanding of the pre-service teachers, their responses to cases were weekly investigated. The current study employed the holistic single-case design (Yildirim \& Simsek, 2011). As there was a single unit of analysis (an individual, a school, an organization etc.), this type of design was preferred. In the selection of the study group, the critical case sampling method, one of the purposive sampling methods, was used (Yildirim \& Simsek, 2011).

\section{Study Group}

The current study was conducted on 32 students having 32 different science teachers and attending 32 different secondary schools located in the city of Denizli (in the west of Turkey) in the fall term of 2018-2019 school year. The students were selected by using the critical sampling method, one of the purposive sampling methods. The students included in the study group were the most successful students of the designated classes according to their classroom teachers. Each of the students interviewed has a different science teacher and each of the students is from a different class or a different school. Some demographic features of the participating students are given in Table 1. 
Table 1. Demographic features of the students in the study group

\begin{tabular}{llcc}
\hline Variables & & f & \% \\
\hline \multirow{2}{*}{ Gender } & Female & 18 & 56.25 \\
& Male & 14 & 43.75 \\
\hline \multirow{3}{*}{ Grade level } & 5th grade & 6 & 18.75 \\
& 6th grade & 9 & 28.12 \\
& 7th grade & 8 & 25 \\
& 8th grade & 9 & 28.12 \\
\hline
\end{tabular}

As can be seen in Table 1, the study group of the current research was comprised of 32 secondary school students. Of the participating students, 18 (56.25\%) were girls, and 14 (43.75\%) were boys. Of these 32 students, $6(18.75 \%)$ were 5 th graders, $9(28.1 \%)$ were 6th graders, $8(25 \%)$ were 7 th graders, and $9(28.1 \%)$ were 8 th graders.

\section{Data Collection Instruments}

The data in the current study were collected by using a semi-structured interview form. While preparing the interview questions, first the related literature was reviewed. Then the content validity was established through the review of two experts, associate professors in science teaching. Piloting of the interview questions was performed with two students, and their responses were recorded in writing to check whether they are comprehensible and the compliance of the responses with the questions. After that, one expert was asked to check whether the questions are clear and understandable, and whether they cover the subject of the research. In this way, internal validity of the questions was established. As known, the internal validity concerns whether the subject of research to be investigated by the researcher can really be explored with the instrument and method to be used (Yildirim \& Simsek, 2005). After the establishment of the validity of the questions, the actual application was initiated, and face-to-face interviews were conducted by the researcher with the students.

The participating students were first informed about the purpose of the study, and their consent was gained to taperecord the interviews. The interviews were conducted in settings where students could feel comfortable, and healthy interviews could be conducted. The interviews conducted with the students lasted 20-25 minutes on average. The interview data were entered into computer environment. Before conducting the interviews with the students, consents were gained from school administrations, parents and students themselves. As consents were gained for 32 students, the current research was conducted on these 32 students.

\section{Data Analysis}

In the analysis of the collected data, the descriptive analysis technique was used. The descriptive analysis was performed through four stages. In the first stage, the researcher constructed a framework for data analysis on the basis of research questions, the theoretical framework of the study or interviews and observations. In this way, it was determined under which themes data would be organized and presented. Then, the researcher read and organized the data on the basis of the framework previously established. In this process, bringing data together in a meaningful and reasonable manner is of great importance. After that, the researcher defined the data he/she had organized. To do so, he/she may feel obliged to use direct quotations in proper places. At the end of this process, the researcher explained, related and made sense of the findings he/she had already defined. In this stage, the researcher explained cause and effect relationships between the findings to reinforce his/her interpretations and made comparison between different phenomena when necessary (Yildirim \& Simsek, 2005). During the analyses, each student was given a code (S1, S2...). Then explanations were made. The data were collected through the interview technique were digitized, and they were expressed in the form of frequencies and percentages. After the transcription of the interview data, written forms of the data were given to the students for confirmation.

\section{Findings/Results}

\section{Findings Obtained from the Interviews with Students}

The data of the current study were collected through the interviews conducted with 32 students having different science teachers and attending different secondary schools located in the city of Denizli in the fall term of 2018-2019 academic year. The findings obtained from the interviews are presented in tables below. The responses given by the students to the question "Do the students like their science teachers and science courses?" are presented in Table 2. 
Table 2. Secondary school students' opinions about their science courses and science teachers

\begin{tabular}{|c|c|c|c|}
\hline They like or dislike the course and the teacher & & $\mathbf{f}$ & $\%$ \\
\hline \multirow{2}{*}{ Like the course } & Yes & 27 & 84.37 \\
\hline & No & 5 & 15.63 \\
\hline \multirow{2}{*}{ Like the teacher } & Yes & 27 & 84.37 \\
\hline & No & 5 & 15.63 \\
\hline
\end{tabular}

Some student opinions in relation to liking or disliking the course and the teacher are given below:

"In the past, I didn't like the teacher and the course. But now, as I like my science teacher, I also like the science course. My teacher is wonderful" (S.9.-7th grade-Girl).

"As I don't like my teacher, I do not like the course because no matter which course it is, if I like the teacher, then I like the course. For instance, last year I had a different science teacher, and then I used to like the science course" (S.13.-8th gradeBoy).

The responses given by the students to the question "How do the students define their science teachers' personality features and how do they want the personality features of their teachers to be?" are summarized in Table 3.

Table 3. Secondary school students' opinions about the personality characteristics of the teacher

\begin{tabular}{|c|c|c|c|c|c|}
\hline \multicolumn{6}{|c|}{ Opinions about the personality characteristics of the teacher } \\
\hline The current state & $\mathbf{f}$ & $\%$ & The desired state & $\mathbf{f}$ & $\%$ \\
\hline Nervous & 10 & 31.2 & Witty & 10 & 31.2 \\
\hline Compassionate & 13 & 40.6 & Funny & 10 & 31.2 \\
\hline \multirow{2}{*}{$\begin{array}{l}\text { Sometimes nervous, sometimes } \\
\text { compassionate }\end{array}$} & \multirow[t]{2}{*}{9} & \multirow{2}{*}{28.2} & Entertaining & 15 & 46,9 \\
\hline & & & Compassionate & 5 & 15,6 \\
\hline
\end{tabular}

Some student opinions about the personality characteristics of their science teachers are given below:

"My science teacher is a 38-year old woman, and she is very nervous. She is always shouting. I do not like her at all. I wish I had a more entertaining teacher" (S.5-5th grade-Boy).

"My science teacher is very compassionate. He/she treats us very well. I want my science teacher to be compassionate like the one I have now" (S.10-6 th grade-Girl).

"Our science teacher is sometimes nervous and sometimes compassionate. However, I would like my teacher to be more entertaining. For example, I know that students learn best within the first 15 minutes, so If I were a teacher, I would allow them to conduct experiments in the first fifteen minutes and then tell jokes and entertain them" (S.32-7th grade-Boy).

The responses given by the students to the question "How do the students think that their science teachers deliver their science classes and how do they want their classes to be instructed?" are summarized in Table 4.

Tablo 4. Secondary school students' opinions about the delivery of science classes

\begin{tabular}{|c|c|c|c|c|c|}
\hline \multicolumn{6}{|c|}{ Delivery of the lesson } \\
\hline The current state & $\mathbf{f}$ & $\%$ & The desired state & $\mathbf{f}$ & $\%$ \\
\hline Lecturing & 32 & 100 & Conducting experiments & 30 & 93.75 \\
\hline Question-answer & 28 & 87.5 & Playing related games & 27 & 84.37 \\
\hline Note-taking & 26 & 81.3 & Not wanting students to write & 26 & 81.25 \\
\hline Morpa, Eba programs are used & 17 & 53.1 & Visual demonstration with videos & 16 & 50 \\
\hline Laboratory & 12 & 37.3 & Activity & 12 & 37.5 \\
\hline -Demonstration experiments & 9 & 28.13 & Students are more active & 11 & 34.37 \\
\hline -Group experiments & 3 & 9.4 & Teaching on the smart board & 8 & 25 \\
\hline Question solving & 10 & 31.3 & Allowing us to discuss questions & 3 & 9.4 \\
\hline Use of smart board & 8 & 25 & Teaching through narration & 3 & 9.4 \\
\hline Teaching through models & 4 & 12.5 & & & \\
\hline Discussion & 3 & 9.4 & & & \\
\hline Teaching through games & 2 & 6.3 & & & \\
\hline
\end{tabular}

Some student opinions about the delivery of science lessons are given below: 
"The teacher, for example, asks a question and then asks us to solve it individually. In my opinion, it should not be so. I had better solve questions by discussing with my peers or in groups. I want it to be so" (S.13-8 ${ }^{\text {th }}$ grade-Boy).

"The teacher talks a lot expressing subjects on the board. He/she tries to put it into our minds. We never use the textbook. $\mathrm{He} / \mathrm{sh}$ asks questions to the students not interested in the lesson. If they correctly answer, then he/she starts to teach another subject; otherwise, goes on teaching the same subject on the board. He/she sometimes uses Morpa for us to see extra explanations about the subject. He/she teaches as he/she wishes" (S.30-8 ${ }^{\text {th }}$ grade-Boy).

"There is a laboratory, but the problem is how we use it: The teacher takes us to the laboratory while teaching some units and we perform experiments there. However, the experiment is carried out in front of the teacher. As it is not performed in front of us, everybody gathers around the teacher. Thus, some students cannot see how the experiment is done. If everybody had the equipment required for the experiment, if everybody could do the experiment, it would be better" (S.11-7th gradeGirl).

"Once, the teacher brought a model while teaching a unit. He/she brought the model of what he/she was trying to teach us. $\mathrm{He} / \mathrm{sh}$ thought the subject on the model. Then, I understood the subject better. We even touched the model during the break. If this had been the common method of instruction, I would have understood the subjects better" (S.5-5th grade-Boy).

"Lecturing but he/she is too fast and we cannot keep up with him/her. He/she makes us write a lot. I do not like writing. I cannot understand the subjects including operations when I write. In my opinion, I would learn better if we did an activity in each lesson. I cannot learn as he/she is too fast to follow. I think it would be better if we could conduct experiments and inquiries about the subject" (S.27-8 ${ }^{\text {th }}$ grade-Girl).

"First, we are instructed about the subject. That is, the teacher teaches the subject. Then, we conduct experiments. We are doing the experiments together with the teacher. Finally we take a test about the subject. We watch videos from Morpa or Okulistik. The lessons are delivered in this way in general" (S.10-6th grade-Girl).

"We do the experiments in groups. The teacher forms groups of 5-6 students. One of the students in the group is a note taker, another one is a narrator, and another one is a performer. It is not good. If our teacher did and explained it, it would be better" (S.20-6 th grade-Girl).

The responses given by the students to the question "How do the students think that their science teachers check what has been learned in a class?" are summarized in Table 5.

Table 5. Secondary school students' opinions about the methods used by their teachers to check their learning

\begin{tabular}{lcc}
\hline Methods used by the teachers to check students' learning & f & \% \\
\hline At the beginning of the lesson, asking questions about the previous lesson & 30 & 93.75 \\
Oral exams & 6 & 18.75 \\
Giving end-of-unit quizzes & 16 & 50 \\
Giving tests & 9 & 28.12 \\
Making students keep journals & 3 & 9.37 \\
\hline
\end{tabular}

Some student opinions about their teachers' methods of checking what they have learned are given below:

"As we are in the $8^{\text {th }}$ grade, our teacher puts great efforts to finish the subject and make us solve tests about the subject. When I go home, I forget everything. We are preparing for the national exam this year. Our teacher thinks that every type of activity apart from tests is useless" (S.29-8 ${ }^{\text {th }}$ grade-Boy).

"He/she makes us keep journals. That is, we are writing the summary of each lesson in a different notebook. At the end of each unit, we show our journals to our teacher and he/she checks them" (S.21.-6 ${ }^{\text {th }}$ grade-Girl)

"The teacher shows the questions on the smart board. And then he/she asks us to solve them. In this way, he/she checks how well we have understood. We are taking tests in a way." (S.29-8 ${ }^{\text {th }}$ grade-Girl).

The responses given by the students to the question "What kind of assignments do the students think they are given by their science teachers?” are summarized in Table 6. 
Table 6. Secondary school students' opinions the state of their teachers' assigning homework and how they assign homework

\begin{tabular}{llcc}
\hline \multicolumn{2}{l}{ Teachers' state of assigning homework and how they do this } & f & $\%$ \\
\hline Doesn't assign homework & Asks us to revise at home & 10 & 31.25 \\
\hline \multirow{3}{*}{ Assigns homework } & Asks us to solve tests in the textbook & 10 & 31.25 \\
& Asks us to solve end-of-unit tests & 7 & 21.87 \\
& Assigns project works & 5 & 15.62 \\
\hline
\end{tabular}

Some student opinions about their teachers' way of assigning homework are given below:

"He/she doesn't give homework. Just asks us to revise at home. In my opinion, it would be better if he/she assigned homework. I cannot figure out how to revise. I do not want to read it from the textbook. I get bored. That is, I do not know how to study" (S.28-6 th grade-Boy).

"He/she sometimes assigns project work. Once I installed circuits. I designed a night lamp. But it is very rare" (S.28-5th grade-Boy).

"He/she assigns us project works, such as skeleton model, lunar eclipse model. I would like to do projects not at home, but together with my friends in the class. I am doing them at home with my mother. I do it at home on my own" (S.17-6th gradeGirl).

"Our teacher is always asking us to do tests at home. As we are preparing for the exam, we are always taking tests. He/she is continuously giving us tests from different sources and wants us to solve them at home. I am bored of doing tests" (S.138the grade-Boy).

The responses given by the students to the question "How do the students think their science teachers ensure discipline in the class?" are summarized in Table 7.

Table 7. Secondary school students' opinions about the means employed by their science teachers to address discipline problems in the class

\begin{tabular}{lcc}
\hline Means employed by teachers to address the discipline problems in the class & $\mathbf{f}$ & $\mathbf{\%}$ \\
Warning & 26 & 81.25 \\
Getting angry & 19 & 59.38 \\
Shouting & 18 & 56.25 \\
Hitting the table & 12 & 37.5 \\
Making the student stand on one foot & 7 & 21.87 \\
Giving minus to the students talking & 17 & 53.12 \\
Calling parents & 1 & 3.12 \\
The game of protect your hundred & 2 & 6.25 \\
\hline
\end{tabular}

Some student opinions about their teachers' ways of addressing the discipline problems in the class are given below:

"As our class is too noisy, our teacher made up a game called "protect your hundred". Due to this game, some of our friends lost some points. While normally talking in the class, you may lose some points. We are given two grades from oral exams. In order to be able to get 100 points from both of them, you need to be as quiet as a church mouse. That is, the teacher says if you want 100 points, you need to keep silent" (S.24-6 th grade-Boy).

"He/she warns us once, or twice. Then he/she makes us stand on one foot" (S.28-6 ${ }^{\text {th }}$ grade-Boy).

"Our teacher gets angry with the students talking in the class" (S.32-7th grade-Boy).

"He/she shouts at the students talking too much in the class" (S.12-5th grade-Boy).

"He/she gives minus to those talking little while making those talking too much stand on one foot during the break" (S.7-6"th grade-Girl).

"He/she shouts at my friend a lot. My friend laughs at him/her when he/she turns back. My teacher has warned him/her many times but he/she doesn't understand" (S.18-5th grade-Girl).

The responses given by the students to the question "Do the students think that their science teachers capitalize on informal learning environments?" are summarized in Table 8. 
Table 8. Secondary school students' opinions about the use of informal learning environments

\begin{tabular}{lccc}
\hline \multicolumn{1}{l}{ Teachers' state of making use of informal learning environments } & f & \% \\
\hline \multirow{3}{*}{ Uses them } & Experiments or observations made in the school garden & 4 & 12.5 \\
& Going to science festivals & 3 & 9.37 \\
& Visiting zoos & 1 & 3.12 \\
& Factory visit (Glass factory) & 1 & 3.12 \\
& Visiting EXPO fair & 1 & 3.12 \\
\hline Doesn't use them & Not being in informal learning environments & 22 & 68.75 \\
\hline
\end{tabular}

Some student opinions about the use of informal learning environments are given below:

"This year, our teacher took us to a science fair organized by a university. We saw the projects made by university students. I liked it. It was nice. It was a good change for us. We also watched a presentation about planets" (S.20-6 ${ }^{\text {th }}$ grade-Girl).

"It was humid one day; we examined the warms in the garden with magnifying glasses. I enjoyed it a lot. I like it more in this way. It would not be so interesting if I read about worms in a book" (S.14-5 th grade-Girl).

"Our teacher took us to a zoo so that we could get to know other creatures better. We grouped the animals after we had a tour in the zoo. It was fun" (S.19-5 th grade-Girl).

\section{Discussion and Conclusion}

Teachers should pay great attention to their interactions with their students. The current study has revealed that the students loving their teachers also like their science classes. The findings of the current study concur with the findings reported by Ozata-Yucel and Ozkan (2011). In a similar manner, in their study, Gomleksiz and Yuksel (2003) found that the relationship between the teacher and the student is not good and this negatively affects their attitudes towards science class. Moreover, when the related literature is reviewed, it is seen that the extent to which love felt for the science course has a significant effect on the attitudes towards the science course (Yildirim, 2017). Kayri, Elkonca, Sevgin and Ceyhan (2014) found the attitudes of the students loving the science course are significantly more positive than the attitudes of the students not loving it. The attitudes of the students not loving the science course are negative to a great extent. Similar studies have also revealed that the attitudes of students loving the science course towards science classes are significantly positive (Akcoltekin \& Dogan, 2013; Yaman, Deniz \& Akyigit, 2010). Therefore, special importance should be attached to developing positive attitudes towards science classes in students and eliminating their prejudices against them.

Of the participating students, 31.2\% find their science teacher nervous, $40.6 \%$ find him/her compassionate and $28.1 \%$ find him/her sometimes nervous and sometimes compassionate. However, $46.9 \%$ of the students would like their science teacher to be entertaining, \%31,2 would like him/her to be humorous, $31.2 \%$ would like him/her to be funny and $15.6 \%$ would like him/her to be compassionate. These findings of the current study are parallel to the findings reported by Can and Arslan (2018). In their study, Can and Arslan (2018) found that majority of the students would like their teachers to be humorous, entertaining and cheerful. The findings reported by Cakmak (2011) have revealed that teachers should demonstrate their humorous side when needed to create a positive classroom atmosphere. While summarizing the work ethics of teachers, Yilmaz (2005) stressed that teachers should be compassionate and humorous, and that the teachers having these characteristics can make lessons more enjoyable, reduce the anxiety in the class and minimize discipline problems on condition that they use them properly.

The students stated that their science teachers use the lecturing method most in their lessons (100\%), and then the question-answer technique (87.5\%). They also stated that their teachers have them write a lot in lessons (81.3\%). According to the students, the classroom activities used in science classes by teachers are generally verbal activities. Other activities such as role-playing, conducting experiments, using models to teach the subject and drama were found to be rarely used in science classes. According to Aktepe and Aktepe (2009), the most frequently used method in science teaching is "lecturing". The lecturing method is easy to use and economical. It allows the effective use of time as the flow of the lesson is not interrupted and makes the teacher feel secure as there won't be any surprise. On the other hand, as it requires students to be passive, it can be boring and the resulting emotional attitudes and behaviours may negatively affect learning. When the relevant literature is reviewed, it is seen that teachers generally prefer to make use of instructional strategies, methods and techniques that can be controlled by the teacher and that can be verbally applied [question-answer, discussion etc.] (Oh \& Kim, 2013; Simsek, Hirca \& Coskun, 2012; Uzal, Erdem \& Ersoy, 2015). As understood from both this current research and national and international studies on the subject, although the learning/teaching approaches that make up the curriculum change over time, it seems to be quite difficult for teachers to abandon traditional methods and to convert teacher-centred classroom environments into student-centred classroom environments. According to Bardak and Karamustafaoglu (2016), this may be due to the fact that 
experienced teachers do not change the teaching styles that have formed over time. However, as stated in Aydin (2003), if the society of tomorrow is attempted to be built with the program of yesterday, the result will be frustration and such an education system will not contribute to educating individuals in line with the needs and expectations of the society.

Of the participating students, 53.1\% stated that their science teachers use interactive instructional media (e.g. EBA, Morpa ...) in their science classes. The students seem to have enjoyed the use of interactive instructional media in their science classes as $50 \%$ of them wanted the use of visual presentations by means of videos. In their study conducted to investigate the application of the FATIH project, Keles and Turan (2015) found that teachers use EBA while preparing and presenting their lessons. However, in a study conducted by Alabay (2015) with the participation of both students and teachers, it was found that teachers do not make much use of EBA while presenting their lessons. Guvendi (2014) conducted a study on 397 elementary, middle and high school teachers and found that 348 of the participants do not use the EBA platform. In a similar manner, Kurtdede-Fidan, Erbasan and Kolsuz (2016), in their study with classroom teachers, found that the participants do not frequently use the EBA platform. In a study conducted by Tutar (2015) on 203 elementary, middle and high school teachers, it was found that nearly half of the participants use EBA at school or in class while the other half of the participants very rarely use EBA.

A great majority of the students (93.75\%) stating their opinions about how lessons are delivered said that they would like to perform experiments in their science classes. According to Yildirim (2017), the variable of the frequency of doing experiment-activity leads to significant difference in the attitudes towards science classes; thus, it can be suggested that more importance should be attached to doing experiments and activities and using laboratories within the context of science course. The reason for students' desiring to do more experiments and activities in science classes can be because they allow them to learn by doing and experiencing and make students more active in the learning process. In this regard, given that experiments and activities are indispensable parts of science education, that they are found to be interesting by students, that they allow students to learn by doing and experiencing, that meaningful learning can be promoted by means of experiments and activities to be conducted in laboratory settings as they will help students reify abstract concepts and that experiments and activities can positively affect attitudes towards science, they should be allocated more space in science classes. Kozcu-Cakir, Senler and Gocmen-Taskin (2007) found that attitudes towards the science course vary significantly depending on the use of laboratory in science classes. This difference is in favor of the frequent use of laboratory. In their study, Kaya and Boyuk (2011b) concluded that students find science experiments exciting, think that they can realize more permanent learning in science classes when experiments are conducted and find science classes very useful as they are provided with opportunities to work with their peers. In some other research, laboratory applications were found to be more conducive to academic achievement, to the development of scientific skills and to the development of positive attitudes towards the course compared to traditional methods (Guney, 2015; Koklu, 2015; Yucel, 2014). On the other hand, research has revealed that due to factors such as teachers' lack of knowledge about equipment, crowded classrooms and inadequate tools and devices, teachers do not exploit laboratory applications much; instead, they prefer traditional methods in their classes (Kaya \& Boyuk, 2011a; Ulucinar, Cansaran \& Karaca ,2004).

Again a great majority of the students (84.37\%) would like their science classes to be taught by means of games. In a study conducted by Altiparmak, Aklar and Dursun (2017), it was also found that the participating students would like their math classes to be delivered through games. These findings concur with the findings of the current study. In their study, Bayat, Kilicaslan and Senturk (2014) concluded that instruction supported with educational games in science classes positively affected academic achievement. According to Yildiz, Simsek and Araz (2016), through instructional games, environments where students can have a good time can be generated and science subjects can be studied in an enjoyable manner. By making changes to classroom applications, more enjoyable learning settings can be created. Through games, the subjects to be studied in the class can be rendered more interesting. Students actively participating in the learning-teaching process can develop their skills such as reasoning, planning, problem solving, strategic thinking, taking responsibility, communication, decision-making, fast thinking, cooperation and socialization by means of instructional games.

Majority of the students (81.25\%) stated that they do not want to write in science classes. The writing activity employed most by the teachers is note-taking. As stated by Gunel, Atila and Buyukkasap (2009), traditional writing activities require students to passively record the information conveyed by the teacher in the class. The main reason for science teachers' using writing as an activity is their wanting their students to record what has been studied in the class. As note-taking is the writing activity most frequently preferred by teachers, it seems to be quite normal for them to encourage their students to record what has been studied in the class. Herr (2008) emphasizes that note-taking makes learning more permanent. According to Erduran-Avci and Akcay (2012), the negative outcomes mentioned by teachers most commonly as related to writing are students' getting bored, writing slowly and shortage of time. These negative outcomes occur as a natural result of note-taking activity as it requires students to write passively what has been said by their teachers. However, Keys (2000) argues that the use of writing activities in a questioning manner can make important contributions to learning.

When the students' opinions about how science classes are instructed are examined, it is seen that $50 \%$ of them would like visual presentations through videos, $37.5 \%$ would like to get engaged in activities in science classes, $34.37 \%$ would 
like students to be more active in science classes, $28.13 \%$ want their teachers to bring models to the class, $25 \%$ want their teachers to use smart boards to teach science subjects, $9.4 \%$ want to solve problems by discussing with their peers and 9.4\% want to be taught through narrations of the subjects. According to Yilmaz (2013), methods and techniques that will endear any course should enable students to enjoy themselves while learning, should be found interesting by students and should make students feel comfortable while using them. Twenty five percent of the students stated that their teachers use the smart board. While Emre, Kaya, Ozdemir and Kaya (2011) stated that the use of smart boards in science education would increase students' motivation, Warnock, Boykin and Tung (2008) concluded that the use of smart boards increased the student motivation and did not affect student performance.

In the current study, it was determined that the teachers use different methods to check whether their students have learned what has been studied in the class. When the students' responses to the question how their teachers check their learning are examined, it is seen that according to $93.75 \%$ of the students, the method used by their teachers to check their learning is asking questions at the beginning of the lesson about the subjects studied in the previous lesson. $50 \%$ of the students stated that their teachers use end-of-unit quizzes, $28.12 \%$ stated that their teachers give them tests, $18.75 \%$ of the students stated that their teachers prefer oral exams to check their learning and $9.37 \%$ stated that their teachers make them keep journals and then collect these journals and evaluate them. According to Nitko (2004), many learning objectives regarding the basic concept knowledge and applications can be tested through widely used measurement techniques known as pen-and-paper tests economically. However, he emphasizes that common measurement methods fall short in the evaluation of higher order cognitive skills such as problem-solving that any education system wants to impart to students and are defined as skills needed to survive in today's world. In a study conducted by Yapici and Demirdelen (2007) on elementary school second level teachers, the teachers' opinions about the measurement and evaluation in the new curriculum were explored and it was found that measurement and evaluation take much time of the teachers (87\%). Moreover, $83 \%$ of the teachers explicitly stated that they use traditional measurement techniques. Another important finding of the study was that there is a need for more inservice training about measurement and evaluation. In a study by Gozutok et al. (2005), it was found that the subject on which teachers felt most concerned about during in-service training seminars was found to be measurement and evaluation. In a similar study conducted by Kucukahmet (2005), one of the weakest aspects of the curriculum was found to be evaluation.

Of the participating students in the current study, 31.25\% stated that their science teachers do not give them homework, but ask them to revise at home while $68.75 \%$ of the students stated that their science teachers assign them homework. In relation to type of the homework assigned to them, $31.25 \%$ of the students stated that their teachers assign tests as homework from the textbook, $21.87 \%$ of them stated that their teachers ask them to do end-of-unit tests and $15.62 \%$ stated that their teachers assign project works. Aladag and Dogu (2009) also evaluated the homework assigned in science classes on the basis of students' opinions. They found that according to the students, homework assigned can play an important role in understanding science subjects and reinforcing their learning. Teachers' checking their students' homework makes students attach greater importance to assignments and improves studentteacher interaction. The homework done in groups by students was found to be increasing permanent learning. Relating assignments to up-to-date topics makes students more willing to do homework and makes them more able in interpreting such up-to-date topics. Assignments help students practice, evaluate and reinforce the shills learned in the class. According to Buyuktokatli (2009), while there are some arguments for the positive sides of assignments and their positive contributions to academic achievement, there are some other arguments against them as they are useless and waste of students' precious time. These negative arguments against homework may be because some assignments may not comply with the objectives of the course and the amount of homework given to students is too much. Thus, homework can be rendered a useful tool if some mistakes committed in the application of homework assignment techniques are corrected and these techniques can be improved.

In the current study, according to the students, the method most commonly used by their teachers to address discipline problems in the class is warning (81.25\%), followed by getting angry with students $(59.38 \%)$, shouting at students (56.25\%), giving minus to the students talking (53.12\%), hitting the table (37.5\%), making the student stand on one foot $(21.87 \%)$, playing the game of protect your hundred (6.25\%) and calling parents (3.12\%). Elban (2009) reported that the methods used by teachers to deal with undesired behaviors are "verbal warning", "ignoring", "warning with body language", "talking to the student individually", "depriving of something loved" and "calling the student's parents". According to Keskin (2002), the approaches most utilized by teachers are verbal warning, talking to the student outside the class, meeting with the family and talking to the student in the class. The approaches utilized the least by teachers are giving physical punishments, assigning unwanted tasks, talking to the school administration, depriving the student of the loved things. Cetin (2013) found that the participating teachers offer the following suggestions to deal with discipline problems; giving rewards and punishments, warning, ignoring, establishing closer relationships with students, providing students with opportunities to interact with their peers through activities, offering counseling services, assigning tasks, making students seated closer to him/her, making students play.

According to the participating students, most of the science teachers do not make use of informal learning environments. However, according to $\mathrm{MoE}$ (2018); in order for students to learn information meaningfully and 
permanently, classroom/in-school and out-of-school learning environments are designed according to the researchinquiry-based learning strategy. In this context, informal learning environments (school garden, science centers, museums, planetariums, zoos, botanical gardens, natural environments, etc.) are capitalized on. In the study carried out by Cicek and Sarac (2017), interviews were conducted with science teachers, and during these interviews, the teachers stated that the activities performed in informal learning environments allow students to practice what they have learned in science classes, contribute to the training of science literate individuals and in these environments they can create learning environments that can cater to individual differences. However, that they encounter some problems in such environments like disciplining students, transportation and eating. Turkmen (2010) maintains that school gardens are ideal places of informal learning. Eshach (2007) points out that informal learning environments make students more willing to learn by increasing their interest and motivation. Bozdogan, Okur and Kasap (2015) argue that learning by doing and experiencing improves the retention of information. In spite of these positive effects of informal learning environments, teachers do not much include them in their teaching (Carrier, 2009; Moseley, Reinke \& Bookout, 2002; Orion, Hofstein, Tamir \& Giddings, 1997).

The number of objectives and the scope of subjects were reduced in the science curriculum renewed in 2013 when compared to the 2004 science curriculum. Moreover, the new curriculum is built on the inquiry and research-based learning strategy requiring student-centered learning environments where learning occurs by doing and experiencing. However, on the basis of the students' opinions elicited in the current study, it seems that the inquiry and researchbased learning strategy has not been adopted much by the science teachers and the instructional program is still teacher-centered. When the most important problems of science education are examined, it is seen that the most important problem is that students are encouraged to memorize rather than do research, create and develop, which indicates that though the curriculum was renewed, teachers go on using the old methods and techniques (Gunes \& Karasah, 2016). In this respect, the mentoring training needed by science teachers to follow the renewed curriculum should be given. After their graduation from the university, science teachers are left alone and as a result they may not follow the developments in the field and may not know the modern class and activities. Thus, it can be suggested that the quality and quantity of in-service training programs offered to teachers should be increased and these teachers' need for mentoring should be met by both the state and academicians from universities. Moreover, academicians teaching the courses of educational sciences should emphasize practice more than theory.

\section{References}

Akcoltekin, A., \& Dogan, S. (2013). Ilkogretim 6.sinif ogrencilerinin fen bilgisi dersine iliskin kaygilarinin farkli degiskenler acisindan incelenmesi [The Analysis of the concerns of the 6th grade students towards the course of science and technology in terms of different variables]. International Journal of Social Science, 6(2), 13-29.

Aktepe, V., \& Aktepe, L. (2009). Fen ve teknoloji ogretiminde kullanilan ogretim yontemlerine iliskin ogrenci gorusleri: Kirsehir BILSEM ornegi [Teaching method using science and technology education on students' aspects: The example of Kirsehir BILSEM]. Ahi Evran University Journal of Kirsehir Educational Faculty (KEFAD), 10(1), 69-80.

Alabay, A. (2015). Ortaogretim ogretmenlerinin ve ogrencilerinin EBA (egitimde bilisim agi) kullanimina iliskin gorusleri uzerine bir arastirma [A research into secondary education teachers' and students' views on EBA (education information network) usage] (Unpublished master's thesis). Aydin University, Istanbul, Turkey.

Aladag, C., \& Dogu, S. (2009). Fen ve teknoloji dersinde verilen odevlerin ogrenci goruslerine gore degerlendirilmesi [The evaluation of homework which are given at secondary school according to students views]. Selcuk University Journal of Social Sciences Institute, 21, 15-23.

Altiparmak, K., Aklar, M., \& Dursun, G. (2017). Bir gunlugune matematik ogretmeni olsaydim, neler yapardim/yapmazdim: Ogrenci gorusleri [If I were a math teacher for a day, what would I do/ what would not I do: Student perspectives]. YYU Journal of Educational Faculty, 14(1), 1117-1140.

Aydin, B. (2003). Bilgi toplumu olusumunda bireylerin yetistirilmesi ve matematik ogretimi [Training individuals in the process of forming knowledge society and teaching of mathematics]. Pamukkale University Journal of Education, 14(14), 183-190.

Bardak, S., \& Karamustafaoglu, O. (2016). Fen bilimleri ogretmenlerinin kullandiklari ogretim strateji, yontem ve tekniklerin pedagojik alan bilgisi baglaminda incelenmesi [Investigation about using strategies, methods and techniques of science teachers based on pedagogical content knowledge]. Avrasya Education Journal, 5(2), 567-605.

Bayat, S., Kilicaslan, H., \& Senturk, S. (2014). Fen ve teknoloji dersinde egitsel oyunlarin yedinci sinif ogrencilerinin akademik basarisina etkisinin incelenmesi [Analysing the effects of educational games in science and technology course on seventh grade students' academic achievements]. Abant Izzet Baysal University Journal of Education, 14(2), 204-216.

Bozdogan, A. E., Okur, A., \& Kasap, G. (2015). Planli bir alan gezisi icin ornek uygulama: Bir fabrika gezisi [A sample application for a planned field trip: A factory trip]. The Black Sea Journal of Social Sciences, 7(14), 1-12. 
Buyuktokatli, N. (2009). Ilkogretimde ev odevi uygulamalarina iliskin ogretmen goruslerinin incelenmesi [Examining teachers' opinions on homework practices in primary education] (Unpublished master's thesis). Selcuk University, Konya, Turkey.

Byers, A., \& Fitzgerald, M. A. (2002). Networking for leadership, inquiry, and systemic thinking: A new approach to inquiry-based learning. Journal of Science Education and Technology, 11(1), 81-91.

Can, E., \& Arslan, B. (2018). Ogretmenlerin sinif yonetimi yeterliklerine iliskin ogrenci gorusleri [Students' opinions related to the teacher competences on classroom management]. The Black Sea Journal of Social Sciences, 10(18), 95219.

Carrier, S. J. (2009). The effects of outdoor science lessons with elementary school students on preservice teachers' selfefficacy. Journal of Elementary Science Education, 21(2),35-48.

Cakici, Y., \& Ilgaz, G. (2011). An analysis of dissertations about 2004 primary science and technology curriculum in Turkey, from 2005 through 2010. The paper was presented as poster in World Conference on New Trends in Science Education (WCNTSE), Kusadasi, Turkey.

Cakmak, M. (2011). Sinifyonetimi [Classroom management]. Ankara, Turkey: Pegem.

Cetin, B. (2013). Sinifta istenmeyen ogrenci davranislariyla ilgili sinif ogretmenlerinin karsilastiklari sorunlar ve cozum onerileri [Problems that class teachers faced in the classroom related to undesired behaviors and their solutions]. Ahi Evran University Journal of Kirsehir Education Faculty, 14(1), 255-269.

Cicek, O., \& Sarac, E. (2017). Fen bilimleri ogretmenlerinin okul disi ogrenme ortamlarindaki yasantilari ile ilgili gorusleri [Science teachers' opinions about experience in out of school learning environments]. Ahi Evran University Journal of Kirsehir Educational Faculty, 18(3), 504-522.

DeBoer, G. E. (2006). Historical perspectives on inquiry teaching in schools. In L. B. Flick \& N. G. Lederman (Eds.), Scientific inquiry and nature of science. Dordrecht, The Netherlands: Springer.

Emre, I., Kaya, Z., Ozdemir, T. Y., \& Kaya, O. N. (2011). Akilli tahta kullaniminin fen ve teknoloji ogretmen adaylarinin hucre zarinin yapisi konusundaki basarilarina ve bilgi teknolojilerine karsi tutumlarina karsi etkileri [The Success of Prospective Science and Technology Teachers on the Structure of Cell Membrane] The paper was presented in 6th International Advanced Technologies Symposium (IATS'11), Elazig, Turkey.

Elban, L. (2009). Ilkogretimdeki ogretmenlerin istenmeyen ogrenci davranislariyla karsilasma ve cozum bulma durumlarinin incelenmesi [Searching of unwanted student behaviours faced by elementary school teachers and searching of finding solution situations] (Unpublished master's thesis). Selcuk University, Konya, Turkey.

Erduran-Avci, D., \& Akcay, T. (2012). Fen ve teknoloji dersinde yazma etkinlikleri uzerine ogretmen gorusleri [Teachers' views on writing activities in science and technology course]. Journal of Turkish Science Education, 10(2), 48-65.

Eshach, H. (2007). Bridging in-school and out-of-school learning: Formal, non-formal, and informal education. Journal of Science Education and Technology, 16(2), 171-190.

Fullan, M. (2007). The new meaning of educational change (4th ed.). New York, NY: Teachers College.

Gomleksiz, M. N., \& Yuksel, Y. (2003). IIkogretim 4. ve 5. sinif ogrencilerinin fen bilgisi dersine iliskin kaygilari (Elazig ili ornegi). [The anxiety of the fourth and fifth grade students in elementary schools towards science course (Sample of Elazig city)]. Surveys in Eastern Anatolia Region, 3, 71-81.

Guvendi, G. M. (2014). Milli Egitim Bakanligi'nin ogretmenlere sunmus oldugu cevrimici egitim ve paylasim sitelerinin ogretmenlerce kullanim sikliginin belirlenmesi: Egitim bilisim Agi (EBA) [Determination of teachers' usage frequency of online education and sharing websites supplied by the ministry of education: An example of Education Information Technologies Network (EBA)] (Unpublished master's thesis). Sakarya University, Sakarya, Turkey.

Gunel, M., Atila, M. E., \& Buyukkasap, E. (2009). Farkli betimleme modlarinin ogrenme amacli yazma aktivitelerinde kullanimlarinin 6. sinif yasamimizdaki elektrik unitesinin ogrenimin etkisi [The impact of using multi modal representations within writing to learn activities on learning electricity unit at 6th grade]. Elementary Education Online, 8(1), 183-199.

Gunes, H., \& Karasah, S. (2016). The studies in science education from the past to the present and the importance of science education. Journal of Research in Education and Teaching, 5(3), 122-136.

Harlen, W. (2004). A systematic review of the evidence of reliability and validity of assessment by teachers used for summative purposes. London, UK: EPPI-Centre. 
Herr, N. (2008). The sourcebook for teaching science strategies, activities and instructional resources. San Francisco, CA: Jossey-Bass A Wiley.

Kaya, H., \& Boyuk, U. (2011a). Fen bilimleri ogretmenlerinin laboratuvar calismalarina yonelik yeterlikleri [Qualifications of science lectures teachers towards laboratory studies]. Erciyes University Journal of the Institute of Science and Technology, 27(1), 126-134.

Kaya, H., \& Boyuk, U. (2011b). Ilkogretim II. kademe ogrencilerinin fen ve teknoloji dersine ve fen deneylerine karsi tutumlari [Attitudes towards science and technology course and science experiments of the middle school students]. Journal of TUBAV Science, 4(2), 120-130.

Kayri, M., Elkonca, F., Sevgin, H., \& Ceyhan, G. (2014). Ortaokul ogrencilerinin fen ve teknoloji dersine yonelik tutumlarinin Chaid analizi ile incelenmesi [The investigation of secondary school students' attitudes towards science and technology using CHAID analysis]. Journal of Educational Science Research, 4(1), 301-316.

Keles, E., \& Turan, E. (2015) Ogretmenlerin firsatlari arttirma ve teknolojiyi iyilestirme hareketi (FATIH) hakkindaki gorusleri [Teachers' opinions on increasing opportunities and improving technology movement (FATIH)]. The Turkish Journal of Education, 4(2), 17-28.

Keskin, M. A. (2002). Sinif ogretmenlerinin karsilastiklari istenmeyen ogrenci davranislari ve kullandiklari bas etme yollari [Student misbehaviours that classroom teachers confront and the ways they use to cope with them]. (Unpublished master's thesis). Hacettepe University, Ankara, Turkey.

Keys, C. W. (2000). Investigating the thinking processes of eighth grade writers during the composition of a scientific laboratory report. Journal of Research in Science Teaching, 37(7), 676-690.

Kozcu-Cakir, N., Senler, B., \& Gocmen-Taskin, B., (2007). Ilkogretim II. kademe ogrencilerinin fen bilgisi dersine yonelik tutumlarinin belirlenmesi [Determining the attitudes towards science course of second grade students in middle school]. The Journal of Turkish Educational Sciences, 5(4), 637-655.

Kurtdede-Fidan, N., Erbasan, O., \& Kolsuz, S. (2016). Sinif ogretmenlerinin egitim bilisim agindan (EBA) yararlanmaya iliskin gorusleri [Views of primary school teachers about the use of education information network]. The Journal of International Social Research, 9(45), 626-637.

Kucukahmet, Leyla (2005). 2004 Hayat Bilgisi programinin degerlendirilmesi [2004 evaluation of Life Science program] The paper was presented in Reflections in Education: 8th Symposium on New Elementary Education Programs, Kayseri, Turkey.

Lederman, N. G.,Lederman, J. S., \& Antink, A. (2013). Nature of science and scientific inquiry as contexts for the learning of science and achievement of scientific literacy. International Journal of Education in Mathematics, Science and Technology, 1(3), 138-147.

MoE - [Ministry of Education] (2005). Fen dersi ogretim programi (6, 7 ve 8. siniflar). [Science teaching program (6, 7 and 8th grades)]. Ankara, Turkey: Ministry of Education.

MoE - [Ministry of Education] (2018). Fen dersi ogretim programi [Science teaching program]. Ankara, Turkey: Ministry of Education. Retrieved from http://mufredat.meb.gov.tr/Programlar.aspx

Moseley, C., Reinke, K., \& Bookout, V. (2002). The effect of teaching outdoor environmental education on preservice teachers' attitudes toward self-efficacy and outcome expectancy. The Journal of Environmental Education, 34(1), 915.

Nitko, A. J. (2004). Educational assessment of students (4th Ed.). Upper Saddle River, NJ: Merrill.

National Research Council (1996). National Science Education Standards. Retrieved from https://www.csun.edu/science/ref/curriculum/reforms/nses/nses-complete.pdf

National Research Council (2000). Inquiry and the national science education standards. Retrieved from https://www.nap.edu/catalog/9596/inquiry-and-the-national-science-education-standards-a-guide-for

Oh, P. S., \& Kim, K. S. (2013). Pedagogical transformations of science content knowledge in Korean elementary classrooms. International Journal of Science Education, 35(9), 1590-1624.

Orion, N., Hofstein, A., Tamir, P., \& Giddings, G. J. (1997) Development and validation of an instrument for assessing the learning environment of outdoor science activities. Science Education, 81, 161-171.

Ozata-Yucel, E., \& Ozkan, M (2011). SBS fen bilimleri testindeki basarinin dusuk olma nedenleriyle ilgili ogretmen ve ogrenci gorusleri [The view of students and teachers about the reason for low success science tests in SBS exams]. Journal of Uludag University Faculty of Education, 24(2), 537-562. 
Puvirajah, A. (2007). Exploring the quality and credibility of students' argumentation: Teacher facilitated technology embedded scientific inquiry (Unpublished doctoral dissertation). Wayne State University, Decroit, Michigan, USA.

Storey, L. (2007). Doing Interpretative Phenomenological Analysis. In E. Lyons \& A. Coyle (Eds.), Analysing qualitative data in psychology (p.51-64). Los Angeles, CA: SAGE.

Senler, B. (2017). Examination of pre-service science teachers' science teaching self-efficacy beliefs and views about scientific inquiry. Journal of Education, Theory and Practical Research, 3(2), 50-59.

Simsek, H., Hirca, N., \& Coskun, S. (2012). Ilkogretim Fen ve Teknoloji ogretmenlerinin ogretim yontem ve tekniklerini tercih ve uygulama duzeyleri: Sanliurfa ili ornegi [Primary Science and Technology teachers' selection of using teaching methods and techniques and the levels of their applications: The sample of Sanliurfa city]. Mustafa Kemal University Journal of Social Sciences Institute, 9(18), 249-268.

Tutar, M. (2015). Egitim bilisim agi (EBA) sitesine yonelik olarak ogretmenlerin goruslerinin degerlendirilmesi [The evaluation of teachers' perceptions towards education information network (EIN)] (Unpublished master's thesis). Karadeniz Teknik University, Trabzon, Turkey.

Turkmen, H. (2010). Informal (sinif disi) fen bilgisi egitimine tarihsel bakis ve egitimimize entegrasyonu [Informal (out of the class) science education integration into our historical look and education]. Cukurova University Faculty of Education Journal, 3(39), 46-59.

Ulucinar, S., Cansaran, A., \& Karaca, A. (2004). Fen bilimleri laboratuvar uygulamalarinin degerlendirilmesi. [The evaluation of laboratory studies in science]. The Journal of Turkish Educational Sciences, 2(4), 465-475.

Uzal, G., Erdem, A., \& Ersoy, Y. (2015). Bir grup matematik ve fen bilimleri ogretmeninin sinif icinde gerceklestirdikleri ogretim etkinliklerin incelenmesi [A study on teaching activities performed by a group of mathematics and science teachers in classrooms]. The Journal of Buca Faculty of Education, (40), 64-85.

Warnock, S. H., Boykin, N. J., \& Tung, W. C. (2011). Assessment of the impact of smart board technology system use on student learning, satisfaction, and performance. Journal of Research in Education, 21(1), 1-20.

Yaman S., Deniz M., \& Akyigit, G. (2010). Ilkogretim birinci kademe ogrencilerinin fen ogrenmeye yonelik motivasyonlari ile cevreye iliskin tutumlari arasindaki iliski [The relationship between primary school first grade students' motivation towards science learning and their attitudes towards environment]. The paper was presented in IX. National Science and Mathematics Education Congress, Izmir, Turkey.

Yapici, M., \& Demirdelen, C. (2007). Ilkogretim 4. sinif sosyal bilgiler ogretim programina iliskin ogretmen gorusleri [Teachers' views with regard to the primary 4th grade social sciences curriculum]. Elementary Education Online, 6(2), 204-212.

Yildirim, H. I. (2017). Ortaokul ogrencilerinin fen dersine yonelik tutum duzeylerinin bazi degiskenler acisindan incelenmesi-1 [Investigation of secondary school students' attitudes towards science course according to some variables-1]. The Journal of Academic Social Science Studies, (60), 17-40.

Yildirim, A., \& Simsek, H. (2005). Sosyal bilimlerde nitel arastirma yontemleri [Qualitative research methods in the social sciences]. Ankara, Turkey: Seckin.

Yildiz, E., Simsek, U., \& Araz, H. (2016). Dolasim sistemi konusunda egitsel oyun yonteminin kullanilmasinin ogrencilerin akademik basari ve fen ogrenimi motivasyonu uzerine etkisi [The effect of the educational game method on academic achievement and motivation towards science learning in teaching of circulatory system]. Mustafa Kemal University Journal of Graduate School of Social Sciences, 13(36), 20-32.

Yilmaz, B. (2005). Ogretmenlik nasil bir meslektir? [What kind of a profession is teaching?]. In A. M. Sunbul (Ed.), Ogretmenin dunyasi [Teacher's world] (p. 7-22). Ankara, Turkey: Mikro.

Yilmaz, T. (2013). Kavram karikaturleriyle desteklenmis bilimsel hikayelerin ogrencilerin akademik basarilari, tutumlari ve motivasyonlari uzerine etkisi [The effect of the science stories supported with concept cartoons on the students' academic achievement, attitudes and motivations] (Unpublished master's thesis). Celal Bayar University, Manisa, Turkey. 